\title{
The Impact of On-board Food Attributes on Passengers' Satisfaction and Loyalty
}

Tamer M. Abbas
Hanan M. El Gamal

Faculty of Tourism and Hotel Management, Helwan University, Egypt Faculty of Tourism and Hotels, Alexandria University, Egypt

\begin{abstract}
:
The on-board service and meal are the most remembered aspects of passengers' travel experience. Although there is an increase importance of the on-board food service among airline passengers; however, their needs have not been thoroughly researched. Therefore, the main objective of this study is to explore the influence of on-board food attributes on passengers' satisfaction and their intentions to re-use the same airline company. In this study, a quantitative approach (i.e. airline passenger questionnaire) and qualitative approach (i.e. content analysis of passengers' rating/comments) were used. More specifically, a form of questionnaire was designed and distributed randomly among 300 airline passengers. Passengers were selected randomly from nine airline companies, namely Egypt Air, El Ethad Airline, Emirates Air, Filipho Airline, Gulf Airline, Lufthansa Airline, Oman Airline, Saudi Arabian Airlines, and Yemen Airline. The questionnaire consisted of 15 food attributes. The quantitative data were analysed using Mann-Whitney test, Kruskal-Wallis test using SPSS, and structural equation modelling using AMOS. Furthermore, the qualitative data (i.e. passengers' comments and rating) were analyzed using content analysis. The results suggested that nine on-board food attributes (i.e. taste, suitability for all plates, portion size, tray arrangement, cleanliness, texture, temperature, variety, overall quality) made unique and statistically significant contributions to the prediction of passengers' satisfaction. In addition, the results confirmed that passengers' satisfaction with on-board meals positively affects passengers' loyalty. The findings of this study provide important practical implications for both scholars and airline managers.
\end{abstract}

\section{Keywords:}

On-board food catering, food attributes, passengers' satisfaction, passengers' loyalty, structural equation modelling (SEM) 


\section{INTRODUCTION}

Airline industry is essential to global world trade as without airline transportation, such industries as leisure and tourism would suffer and international business activities would become much harder to conduct (Tiernan et al., 2008). Because of the competition among the airline companies all over the world, airlines are forced to shift their focus towards customer-oriented service quality (Chang and Yeh, 2002). Therefore, it is extremely important for airline companies not only to understand the perception of passengers of their service offerings, but as well find out what customers expect from the services and what kind of services customers consider most important (Chen and Chang, 2005). Thus, service quality is a key to attract and keep loyal customers (Chang and Yeh, 2002; Gursoy et al., 2005; Liou and Tzang, 2007).

On-board food is an important dimension of airline services. In particular, Solomon (2002) noted that passengers generally will choose the airline that offers the best food. Further, on-board food services now are seen as part of marketing strategies in attracting all kind of travellers (Jones, 1995). In this regards, King (2001) reported that some passengers would be willing to change airlines, alter travel patterns and even pay more money for the high quality of on-board food served. As a result, many airlines have invested a fortune on on-board food to make their passengers feel their distinctiveness than other airlines companies (Gursoy et al., 2005). In connection with this, many airline caterers put immense efforts into ensuring the quality of the onboard food they serve (Thorpe, 1998).

Although there is an increase importance of the on-board food service among airline passengers; however, their needs have not been thoroughly researched. The majority of previous studies have concentrated on the role of meals provision in airline catering, airline passengers' food-service experiences during long journey, and relationship between the image of airlines and the on-board food served (Williams, 1995; Nomani, 1999; Bennet and Wood, 2002; Eric and Laws, 2005). Therefore, the current study aims to explore the impact of on-board food attributes on passengers' level of satisfaction and loyalty.

\section{LITERATURE REVIEW}

Surveys over a number of years suggested that passengers appear most concerned about safety, punctuality, scheduling convenience, tracking system, the aircraft's physical surroundings such as seat and leg comfort, and 
gate check-in and boarding (Jones, 2004; Eric and Laws, 2005). In 1977, Makens and Marquardt studied the reasons for selecting a particular airline.

These reasons were: ticket price, overall seating comfort, overall spaciousness, length of flight, noise travel, meal and table service, menu selection, prompt deplaning, attention given by hostess, privacy, luggage allowance, storage space at seat, drink price, meeting people socially and making business contacts. Later on, Eliot and Roach (1993) tried to identify the factors that influencing passengers' evaluation of airline carriers. The major factors were: on-time performance, baggage handling, on-board food quality, seat and leg room, check-in service, and in-flight service. Apparently, Elaine (2000) revealed that meals was ranked ninth, in importance to airline carriers after scheduling, punctuality, safety, speedy check-in, route network, comfort, price, and mileage programs.

$\mathrm{Tu}$ (1997) initially argued that although food may not rank high among the top factors in choosing between airlines; however, it can evoke emotional sentiments and it is certainly a key service element for its repeat passengers. Similarly, Jones (2007) pointed that some airlines use on-board food catering as a marketing tool and some others advertise their product by making food the focal point. In this regards, McCool (1995) defined on-board food catering as that part of the food service industry that is concerned with the provision of meals and beverages to passengers on board of aircraft. This food service is usually provided by firms specializing in the flight catering business.

\section{The evolution of on-board food catering}

In 1903, the first flight in the history, there was no food or drink on board of this historic flight. However, it was not long before food and beverage service became a feature of air travel. In August 1919 the first on-board service by aeroplane began in Europe, plain and cream teas were served during the two hour flight (Wright, 2001). During the 1920s Imperial Airways' catering service consisted of only sandwiches with tea or coffee (O'Hara and Strugnell, 1997).

Air Union was the first airline offered full on-board food service. Stewards were hired to serve food on board such as hors d'oeuvres, lobster salad, cold chicken and ham, nicoise salad, ice cream, and cheese and fruit. Drinks such as champagne, wine, whisky, mineral water, and coffee were also served with the meal (Franklin, 1999). Imperial in 1927 introduced a steward on board who served sandwiches, fruit, and coffee from a vacuum flask (Franklin, 1999).

Pan Am US airline had employed uniformed stewards and restaurant-style tables with vases of flowers and silver cutlery. Western Airline served meals 
brought from a restaurant to their aeroplanes. The first full-hot food service was on Sunday, 29 April 1928, when Lufthansa introduced their 'Flying

Dining Car' on the Berlin-Paris route. This aeroplane had a fully equipped galley, where the steward was able to prepare and serve hot food (Franklin, 1999).

In the mid 50s, Boeing 737 aircraft was equipped with modern catering functions and gadgets to enrich the customers' experience. During 1980s, most of the airline companies had their own catering division (Dana, 1999). This situation however changed in the beginning of 1990s when on-board catering was contracted out to specialized flight catering companies. Gate Gourmet, Alpha Flight Services and LSG SKY Chefs are the most famous multi-national caterers who are responsible for preparing thousands of meals for many airline companies nowadays. In fact, these catering companies employ specialist chefs to design menus suitable for an increasingly demanding market (Dana, 1999).

\section{Characteristics of on-board food catering}

McCool (1995) reported that on-board food services are unique in many ways. One example of flight catering unlike any other sector of the catering industry is that the people who prepare, package, and deliver food and beverage consumed by the airline passengers have little opportunity for direct contact with the consumers of their products. Furthermore, Hatakka (2000) assured that the production of aircraft meals is a high-risk mass catering operation that has global dimensions. Microbiological hazards are the most prominent risk factors connected with this kind of food production. Therefore, strict quality assurance based on the hazard analysis of critical control point (HACCP) system should be applied by the flight caterers.

On-board meals preparations are also unique and differ from restaurants' meals, Kirk (1995) listed the following elements as being specialty fields for airline catering chefs: The function of the tray meal; the standardized recipes; the function of ingredients; food safety from the microbiological perspective; various types of passengers; establishing that adequate provision is made for special diets, religions, ethnic meals and vegetarians; the marketing concepts of airlines (i.e. customer demands); the capabilities of the flight kitchen, its labour and equipment; the cost factors.

\section{Passengers' satisfaction and loyalty}

From one hand, customers' satisfaction is defined as "a summary cognitive and affective reaction to a service incident or sometimes to a long-term service relationship" (Rust and Oliver, 1994, p.5). From the other hand, 
customers' loyalty is defined as the process of incorporating the attitudinal and behavioural measures of commitment and repeat purchase (Selin et al.,

1988). In the literature, various factors have been used to measure loyalty, such as purchase intentions, word-of-mouth communications, price sensitivity and complaint behaviour (e.g., Selin et al., 1988; Khatib, 1998).

In service industry, many researchers (e.g., Anderson and Sullivan, 1993; Taylor and Baker, 1994) have discussed the relationship between consumer satisfaction and purchase intentions. They found consumer satisfaction is a factor leading to brand loyalty or repeat purchase behaviour.

Similarly, in airline industry, many researchers (e.g., O'Hara and Strugnell, 1997; Heide et al., 1999; Suzuki, 2004; Park et al., 2005) found that passengers' satisfaction (PS) has a significant impact on passengers' loyalty (PL). Heide et al., (1999) assured that providing good on-board meals and services has generated positive word-of-mouth communication among the passengers. The positive word-of-mouth communication is an important source of information in the selection of airlines. More specifically, Suzuki (2004) pointed that passengers' poor service experience will be shared with seven to nine friends at least. Therefore, service failure may damage the image of the airline and cause a negative impact on passengers' behavioural intentions (Park et al., 2005). However, other researchers (e.g., Khatib, 1998; Hayama, 2002; Dolnicar et al., 2011) argued that the relationship between PS and PL towards a specific airline is less clear. They postulated that on-board meal may not affect pre-purchase decisions; however, it emerges as a highly significant post-purchase factor. The on-board service and meal are the most remembered aspects of people travel experience. Hence, the following hypothesis is posited:

H1: Passengers' satisfaction with on-board meals positively affects passengers' loyalty (i.e. re-flying intention and recommending others).

\section{On-board food attributes and passengers' satisfaction}

In service industry, service quality and consumer satisfaction have been linked together as shown by many previous studies (e.g., Bolton and Drew, 1991; Cronin et al., 2000). These studies showed that service quality has direct and indirect effect on customer satisfaction and behavioural intentions. However, in the airline industry, most of the previous studies focused on specific dimensions of service quality (i.e. skill of airline employee, baggage handling, on-time performance, flight schedule, price, safety records, image, aircraft characteristics, reservation and buying tickets). Additionally, most of the previous studies (e.g., Makens and Marquardt, 1977; Gourdin and Kloppenborg, 1991; Eliot and Roach, 1993; Ostrowski et al., 1993; Khatib, 
1998; Eric and Laws, 2005) focused only on four dimensions of foodservice quality: quality of meals, quantity of meals, menu selection, prompt beverage

and meal. Apparently, there is a lack of consensus in the literature and among researchers about the causal link between the on-board foodservice quality (e.g., meal taste, smell, colour, texture, temperature) and PS.

Additionally, some researchers (i.e. Khatib, 1998; Mohd Zahari et al., 2011) found that quality of meals, quantity of meals, and menu selection had significant impact on the level of PS. However, Hayama (2002) argued that providing a product that will satisfy the customer is about much more than simply providing a ready meal. Similarly, Johnston and Lyth (1991) believed that PS will not be based on a single factor (i.e. on-board meal), but rather will be the result of a combination of several factors that passenger determine to be appropriate in the creation of satisfaction such as safety, and cleanliness of the plane.

In addition, some factors such as the function of the tray size, dish specification, overall tray presentation, the nature of the meals, and the effect of delay on loading on to the aircraft need to be considered when designing a tray set (Park et al., 2005). Further, airlines should offer special meals to meet dietary or religious needs, and also uses the advanced booking of meals to attract more passengers (Dana, 1999; Abdel-Atti, 2003). Bennet and Wood (2002) recommended that the flight caterers should develop new foods and follow the new meals trends to satisfy airline passengers. Based on the above discussion, the following hypotheses are posited (see Figure 1):

H2: Taste of the meal (TA) positively affects passenger's satisfaction (PS).

H3: Smell of the meal (SM) positively affects PS.

H4: Combination of the ingredients use (IN) positively affects PS.

H5: Suitability of the meal for all plates (PL) positively affects PS.

H6: Suitability of the meal cooking method (ME) positively affects PS.

H7: Freshness of the meal (FR) positively affects PS.

H8: Colour combination of the meal (CO) positively affects PS.

H9: Packaging of the meal (PA) positively affects PS.

H10: Portion size of the meal (PO) positively affects PS.

H11: Arrangement of the meal (AR) positively affects PS.

H12: Cleanliness of the meal (CL) positively affects PS.

H13: Texture of the meal (TX) positively affects PS.

H14: Temperature of the meal (TE) positively affects PS.

H15: Variety of the meal positively (VA) affects PS.

H16: Overall quality of the meal (QU) positively affects PS. 
Taste

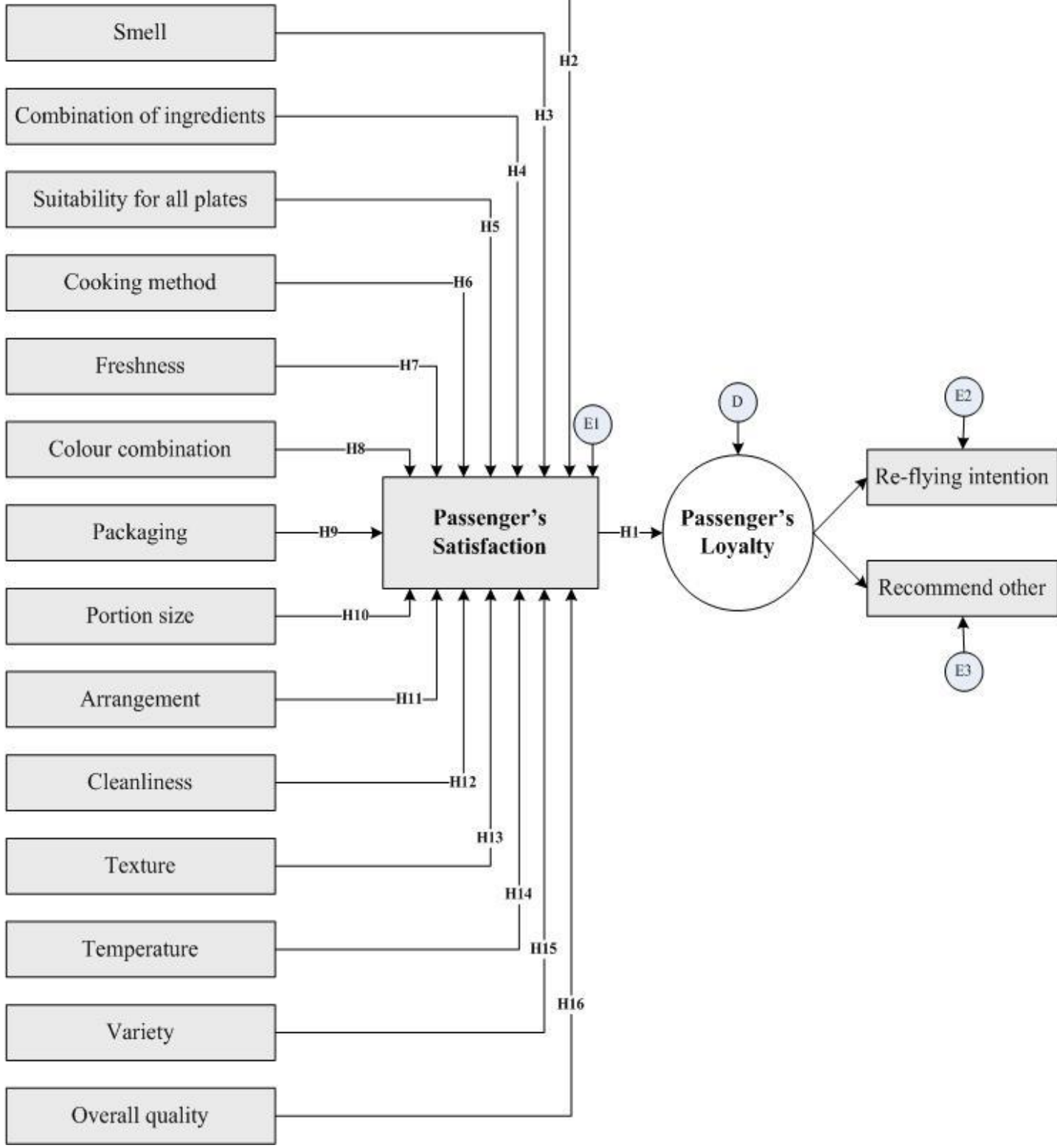

Figure 1: The proposed research model

\section{METHODS}

Two approaches were used in this study, a quantitative approach (i.e. airline passenger questionnaire) and qualitative approach (i.e. content analysis). The 
former can be conducted as a research strategy that emphasizes quantification in the collection and analysis of data and that entails a deductive approach to

the relationship between theory and research, in which the accent is placed on the testing of theories (Bryman and Bell, 2007). It is therefore ideal for this study to use a quantitative research strategy to identify the impact of onboard food attributes on passengers' level of satisfaction and loyalty and recommending others using an instrument in a form of questionnaire. Furthermore, passengers' rating and comments on three airline catering (i.e. Egypt Air, Emirates Air, Saudi Arabian Airlines) were content analyzed. The other six airline catering (i.e. El Ethad Airline, Filipho Airline, Gulf Airline, Lufthansa Airline, Oman Airline, and Yemen Airline) had very limited comments. The Passengers' rating and comments were available at "Airlinemeals.net" website.

\section{On-board food satisfaction measurement scale}

In this research, the questionnaire was adapted and revised from previous research (e.g., Makens and Marquardt, 1977; Gourdin and Kloppenborg, 1991; Eliot and Roach, 1993; Ostrowski et al., 1993; Khatib, 1998; Eric and Laws, 2005). The questionnaire was initially piloted within a panel composed of ten experts to discuss questionnaire scale content, measurement, wording and layout. As the main objective of this study was to investigate the onboard food attributes on passengers' levels of satisfaction and loyalty, a selfreported experience through a questionnaire survey was chosen as the means of data gathering. This approach was opted for to ensure that the information obtained would be based upon actual experiences of consuming the on-board food. The revised questionnaire consists of three major sections. Section (A) was created with the intention of examining the general satisfaction of the passengers with the on-board food attributes; a total of 15 statements were used, respondents were asked to rate their feelings and rate each factor in response to the question 'Please indicate how satisfied you are with the onboard meal quality?' on a five-point Likert scale: 'strongly dissatisfied'; 'dissatisfied'; 'neither satisfied nor dissatisfied; 'satisfied'; and 'strongly satisfied'. Five-point Likert scale was used to increase the response rate because passengers are quite busy at airports. Section (B) was designed using open question models to report their re-flying intention and recommending others, by asking 'Do you think you will re-fly on the same air company if you have the chance' and "Would you recommend others like friends and family to fly on the same air company'. Section (C) was designed using a nominal scale focusing on passengers' demographic profile like age, gender and nationality. Questions such as the frequency of travel and the reason for travel were also included. 


\section{Sampling airline passengers}

The population of interest for this study is airline passengers. Passengers were selected randomly from nine airline companies, namely Egypt Air, El Ethad airline, Emirates Air, Filipho airline, Gulf airline, Lufthansa airline, Oman airline, Saudi Arabian Airlines, and Yemen airline. Convenience sampling was used for selecting airline companies. Questionnaires were distributed to passengers at Alexandria and Cairo International Airports between January and March 2014. A total of 300 questionnaires were distributed to passengers. A total of 212 responses were returned, representing a response rate of $70.7 \%$.

\section{Data analysis}

The qualitative data were analyzed using content analysis. For the quantitative data, structural equation modelling (SEM) was used in this study. SEM can be used to investigate interrelationships between two types of variable: measured and latent. Measured (observed) variables have data that can be directly measured by a researcher. Latent (unobserved) variables or constructs, on the other hand, are variables that are of interest to a researcher but are not directly observable (Tabachnick and Fidell, 2007). Basic SEM consists of two parts: measurement model, and structural model. Measurement model specifies how the observed variables are related to the unobserved, or latent, variables; whereas, structural model specifies how the latent variables are related to each other (Tabachnick and Fidell, 2007; Arbuckle, 2011). In this study, a two-step approach for SEM was used. In the first step, confirmatory factor analysis (CFA) was used to test the measurement model (i.e. passengers' loyalty). In the second step, maximum likelihood was used to estimate the structural model. A software program called Analysis of Moment Structures (AMOS), which is part of the SPSS software suite (Arbuckle, 2011), was used for CFA and SEM. Composite reliability (CR) and Cronbach's $\alpha$ for each latent variable were used to test the construct reliability as well as average variance extracted (AVE) was used to test the construct convergent validity (Hair et al., 2010). Furthermore, Mann-Whitney and Kruskal Wallis tests were used to test for differences between passengers' profile, airline companies, frequency of travelling, travelling class and purpose of travel in terms of their satisfaction and loyalty. 


\section{RESULTS}

\section{A Content analysis of passengers' comments on Airlinemeals.net}

A total of 232 passengers' rating and comments on three airline catering (i.e. Egypt Air, Emirates Air, Saudi Arabian Airlines) were content analyzed. Passengers' rating and comments were available at "Airlinemeals.net" website.

\section{1) Egypt Air:}

Twenty six comments regarding on-board food were obtained from passengers who travelled using Egypt Air during 2008 to 2013. In particular, only 7 passengers had good experiences with in-flight meals regarding taste, portion size, variety, and service, as shown in the following quotes:

"Excellent service and meal, there was a choice between cheese/turkey and cheese/pasta. The cake was really nice. Well done Egypt Air" [Business passenger]

"I was impressed by the service on a very short trip (only lasted 35 minutes). The cabin crew were attentive and the meal fitting" [Business passenger]

"Nice meal, good portion, tasty" [Economy passenger]

However, most passengers (19 out of 26) had bad experiences with in-flight meals regarding taste, suitability for all plates, arrangement, texture, variety, and overall quality:

"One of the worst meals I have had on flights - completely unworthy of first class. The beef was the toughest piece of meat I have encountered in my life - and had to leave it untouched. There were at least two uniformed male hosts who chatted with each other all the time and did absolutely NOTHING! Last time I will travel by Egypt Air!" [First class passenger]

"No choice and very disappointing one tray breakfast, the omelette was tasteless and lacked seasoning" [Business passenger]

"Absolutely in-edible, Salmon was broken up and so un-fresh" [Economy passenger]

\section{2) Emirates Air:}

The comments from 176 passengers who travelled using Emirates Air during 2008 to 2013 were content analyzed. From one hand, only 6 passengers had 
bad experiences with in-flight meals regarding taste, portion-size, texture, and freshness:

"The food seemed to be long standing, the salmon steak was hard and it did not feel fresh at all, the croissant seemed to be old too" [Economy passenger]

From the other hand, almost all passengers (i.e. 170 passengers) had good experiences with Emirates in-flight meals regarding taste, suitability for all plates, portion size, arrangement, cleanliness, texture, temperature, variety, and overall quality, as shown in the following quotes:

"To put it simple: absolutely mind-blowing! It was a feast for the senses. Top level in terms of freshness, arrangement, scent and taste. The meal was cooked to perfection. Seafood was very fresh and tasty. Incredible gastronomic performance aboard an aircraft" [First class passenger]

"Very impressive indeed for an airline meal, everything on the tray was good. The ingredients were very fresh, even the hummour fish. The chicken was tender and flavourful. The dessert was as good as any nice cake shop would serve. Even the tea was good and strong. Anyway, that beautiful piece of small chocolate ended my meal on a good note!" [Business passenger]

"Best meal on Economy I ever had. All fantastic! Emirates offers a nice and friendly service. Food was very tasty and of good quality" [Economy passenger]

\section{3) Saudi Arabian Airlines:}

The comments from 30 passengers who travelled using Saudi Arabian Airline during 2008 to 2013 were content analyzed. All passengers had bad experiences with in-flight meals regarding taste, suitability for all plates, portion size, arrangement, cleanliness, texture, temperature, variety, and overall quality, as shown in the following quotes:

"Fruits were not as fresh as mentioned on the menu" [First class passenger]

"An extremely disappointing meal service for business class, flavourless omelette and dry over night hash and veggies on the plate, the fruit plate was substandard, no menu was provided" [Business passenger]

"Main course was extremely poor with dry chicken and boring tasteless rice" [Economy passenger]

"Although I have documented my special meal preferences for many years, it was not sent correctly as I received a vegetarian meal instead. Nothing special at all. This was my last flight on board SV A300-600 aircraft" [Economy passenger] 


\section{Passengers' profiles}

Table 1 presents the demographic profiles of the passengers who participated in the study. The passengers comprised $66.5 \%$ males and $33.5 \%$ females. They were from various age groups, with the largest group (31.6\%) of passengers aged from 40 up to 50 years old. Passengers were selected randomly from nine airline companies: 39.2\% from Egypt Air, 29.7\% from Saudi Arabian Airlines, $15.1 \%$ from Emirates Air, $16 \%$ from other companies (i.e. El Ethad Airline, Filipho Airline, Gulf Airline, Lufthansa Airline, Oman Airline, and Yemen Airline). Most of the selected passengers (48.1\%) were travelled from 2-3 times per year. In particular, $63.2 \%$ of them were used economy class, followed by $23.6 \%$ were used business class and 13.2\% were used first class. Most of the passengers were travelling for: Business/work (39.2\%), visiting friends or relatives $(19.8 \%)$, and vacation/pleasure (18.9\%).

Table 1: Demographic profiles of passengers $(\mathrm{N}=212)$

\begin{tabular}{|c|c|c|}
\hline Variable & $\mathbf{N}$ & $\%$ \\
\hline \multicolumn{3}{|l|}{ Gender } \\
\hline Female & 71 & 33.5 \\
\hline Male & 141 & 66.5 \\
\hline \multicolumn{3}{|l|}{ Age(years) } \\
\hline Less than 20 & 6 & 2.8 \\
\hline 20 up to 30 & 18 & 8.5 \\
\hline 30 up to 40 & 65 & 30.7 \\
\hline 40 up to 50 & 67 & 31.6 \\
\hline 50 up to 60 & 40 & 18.9 \\
\hline 60 or more & 16 & 7.5 \\
\hline \multicolumn{3}{|l|}{ Airline company } \\
\hline Egypt Air & 83 & 39.2 \\
\hline Saudi Arabian Airlines & 63 & 29.7 \\
\hline Emirates Air & 32 & 15.1 \\
\hline Others & 34 & 16 \\
\hline \multicolumn{3}{|l|}{ Frequency of travel per year } \\
\hline Once & 86 & 40.6 \\
\hline 2-3 times & 102 & 48.1 \\
\hline 4-5 times & 21 & 9.9 \\
\hline More than 5 times & 3 & 1.4 \\
\hline \multicolumn{3}{|l|}{ Travelling class } \\
\hline First class & 28 & 13.2 \\
\hline Business class & 50 & 23.6 \\
\hline Economy & 134 & 63.2 \\
\hline \multicolumn{3}{|l|}{ Purpose of travel } \\
\hline Vacation/pleasure & 40 & 18.9 \\
\hline Culture & 22 & 10.4 \\
\hline Visiting friends or relatives & 42 & 19.8 \\
\hline Therapy & 9 & 4.2 \\
\hline $\begin{array}{l}\text { Business/work (meetings, conventions, } \\
\text { conferences, etc.) }\end{array}$ & 83 & 39.2 \\
\hline
\end{tabular}




\section{A Descriptive analysis of the questionnaire items}

Table 2 shows that all in-flight meal attributes satisfaction items $(\mathrm{n}=15$; $100 \%$ ) had mean and median scores above 2.00. All the factors were rated by passengers as important for their satisfaction. Based on this finding, all items (Mean $\geq 2.00$; Median $\geq 2.00$ ) will be subjected to SEM.

Table 2: A descriptive analysis of the in-flight meal questionnaire

\begin{tabular}{lcccc}
\hline \multicolumn{1}{c}{ Items } & Mean & Median & Mode & Std. Deviation \\
\hline Purpose of the travel & 3.57 & 4.00 & Business & 1.683 \\
Taste of the meal served & 3.62 & 4.00 & Moderate & 1.075 \\
Smell of the meal served & 4.01 & 4.00 & Satisfied & .860 \\
Combination of the ingredients use & 3.81 & 4.00 & Satisfied & .991 \\
Suitability of the meal served for all plates & 3.88 & 4.00 & Satisfied & .913 \\
Suitability of the meal cooking method & 3.88 & 4.00 & Satisfied & .941 \\
Freshness of the meal served & 3.92 & 4.00 & Satisfied & .994 \\
Colour combination of the meal served & 3.78 & 4.00 & Satisfied & .978 \\
Packaging of the meal served & 4.07 & 4.00 & Satisfied & .957 \\
Portion size of the meal served & 3.83 & 4.00 & Satisfied & .899 \\
Arrangement of the meal served & 3.98 & 4.00 & Satisfied & .921 \\
Cleanliness of the meal served & 4.12 & 4.00 & Very satisfied & .889 \\
Texture of the meal served & 3.85 & 4.00 & Satisfied & .940 \\
Temperature of the meal served & 4.06 & 4.00 & Very satisfied & .964 \\
Variety of the meal offered & 3.70 & 4.00 & Satisfied & 1.046 \\
Overall quality of meal served & 3.91 & 4.00 & Satisfied & .824 \\
Overall satisfaction & 3.92 & 4.00 & Satisfied & .836 \\
Re-flying intention & 1.34 & 1.00 & Yes & .702 \\
Recommend others & 1.28 & 1.00 & Yes & .452 \\
\hline
\end{tabular}

\section{Analysis of variance}

Passengers were compared on their scores by gender using a Mann-Whitney test (see Table 3). The Mann-Whitney test revealed statistically significant difference between male and female passengers. More specifically, female passengers had higher scores than male passengers on the smell of the meal, the suitability of cooking method, the packaging, the variety, and the overall quality of the meal served.

Furthermore, passengers were compared on their scores by age, airline company, frequency of travel, travelling class, and purpose of travel using a Kruskal Wallis test (see Table 3). For age, Jonckheere's test revealed a significant trend in the data: as the age increased, the median counts of passengers' scores on food attributes increased. The results also showed significant differences among airline companies regards taste, smell, combination of ingredients, freshness, colour combination, portion size, texture, variety, and as a result differences in passengers' re-flying intention and recommending others. For example, the passengers of Emirates Air were highly satisfied with the taste and the smell of the meal, while the passengers 
of Egypt Air were highly satisfied with the freshness, the colour combination, and the variety of the meal offered.

In addition, the results revealed that as the frequency of travel increased, the median counts of passengers' scores on taste, smell, combination of ingredients, suitability of cooking method, freshness, and texture increased. For the travelling class, Jonckheere's test showed a significant trend in the data: as the higher the travelling class, the higher median counts of passengers' scores on food attributes. In other words, first class passengers were more satisfied with food attributes than business and economy class travellers. The results also showed a significant difference between passengers' scores on food attributes in terms of their purpose of travel. For example, vacation passengers had the highest scores on portion size and variety of the meal, while business passengers had the highest scores on suitability of the meal for all plates.

Table 3: Results of analysis of variance

\begin{tabular}{|c|c|c|c|c|c|c|}
\hline \multirow[b]{2}{*}{ On-board meal items } & \multicolumn{6}{|c|}{ Asymp. Sig. (2-tailed) } \\
\hline & $\begin{array}{l}\text { Gender } \\
\text { groups }\end{array}$ & $\begin{array}{l}\text { Age } \\
\text { groups }\end{array}$ & $\begin{array}{c}\text { Airline } \\
\text { company }\end{array}$ & $\begin{array}{c}\text { Frequency } \\
\text { of travel }\end{array}$ & $\begin{array}{c}\text { Travelling } \\
\text { class }\end{array}$ & $\begin{array}{l}\text { Purpose } \\
\text { of travel }\end{array}$ \\
\hline Taste & .734 & $.027 *$ & $.000 *$ & $.002 *$ & $.005^{*}$ & .051 \\
\hline Smell & $.003 *$ & $.000 *$ & $.013^{*}$ & $.000 *$ & $.000 *$ & .344 \\
\hline Combination of ingredients & .321 & $.006^{*}$ & $.000 *$ & $.014 *$ & $.004 *$ & .105 \\
\hline Suitability for all plates & .495 & $.000 *$ & .212 & .061 & $.000 *$ & $.014 *$ \\
\hline Cooking method & $.042 *$ & $.000 *$ & .119 & $.026 *$ & $.000 *$ & .050 \\
\hline Freshness & .287 & $.000 *$ & $.001 *$ & $.012 *$ & $.000 *$ & .101 \\
\hline Colour combination & .132 & $.000 *$ & $.001 *$ & .052 & $.000 *$ & .067 \\
\hline Packaging & $.048 *$ & $.000 *$ & .087 & .060 & $.000 *$ & .164 \\
\hline Portion size & .283 & $.000 *$ & $.003 *$ & .070 & $.000 *$ & $.008 *$ \\
\hline Arrangement & .588 & $.000 *$ & .076 & .060 & $.000 *$ & .222 \\
\hline Cleanliness & .741 & $.001 *$ & .268 & .082 & $.001 *$ & .300 \\
\hline Texture & .118 & .090 & $.013^{*}$ & $.000^{*}$ & $.000 *$ & .052 \\
\hline Temperature & .236 & .082 & .556 & .081 & $.000 *$ & .150 \\
\hline Variety & $.011 *$ & .054 & $.001 *$ & .072 & $.000 *$ & $.009 *$ \\
\hline Overall quality & $.012 *$ & $.000^{*}$ & .149 & .077 & $.000 *$ & .056 \\
\hline Overall satisfaction & .170 & $.000 *$ & .126 & .082 & $.000 *$ & .052 \\
\hline Re-flying intention & .960 & .091 & $.003 *$ & .176 & $.002 *$ & .065 \\
\hline Recommending others & .101 & .080 & $.001 *$ & .051 & $.000 *$ & .114 \\
\hline
\end{tabular}

$* \mathrm{P}$-value $<0.05=$ Significant difference

\section{Structural Equation Modelling}

\section{Analysis of Measurement Model}

CFA was performed to test the measurement model for the passengers' loyalty using AMOS 20. The results of CFA show that the values of CR and Cronbach's $\alpha$ for all of the constructs exceeded the minimum acceptable value of 0.7 (Hair et al., 2010), indicating a good reliability level. Furthermore, the values of AVE for all of the constructs exceeded the 
minimum acceptable value of 0.5 (Hair et al., 2010), indicating good convergent validity (see Table 4). Additionally, the various measures of the overall model goodness-of-fit suggest a satisfactory model fit. More

specifically, chi-square $\left(\chi^{2}\right)$ value is 70.422 with 55 degrees of freedom, $\mathrm{p}$ $=.122 ; \mathrm{GFI}=0.96 ; \mathrm{AGFI}=0.94 ; \mathrm{NFI}=0.96 ; \mathrm{RFI}=0.93 ; \mathrm{IFI}=0.98 ; \mathrm{TLI}=0.95$; $\mathrm{CFI}=0.98-$ all greater than the recommended level of 0.90 and RMSEA= 0.034 , smaller than the cut off value of 0.05 (Arbuckle, 2011). Another rule for a good-fitting model is that the ratio of the $\chi^{2}$ statistic to the degrees of freedom to be less than 3 (Arbuckle, 2011). The ratio of the model is $70.422 / 55=1.28$. Further, the $t$-values for all the parameter estimates are all statistically significant at the 0.1 percent level. Hence, the measurement model is stable and converges properly.

Table 4: The parameter estimates of the measurement model, validity analysis, and reliability test

\begin{tabular}{lccccc}
\hline \multicolumn{1}{c}{ Latent/Measured variable } & Factor loadings & Path coefficients & CR & AVE & $\boldsymbol{\alpha}$ \\
\hline Passengers' loyalty & & & 0.93 & 0.87 & 0.92 \\
Re-flying intention & 1.00 & 0.94 & & & \\
Recommending others & 1.24 & 0.92 & & & \\
\hline
\end{tabular}

\section{Analysis of Structural Model}

After the CFA was employed, SEM was used to test the path/structural model for passengers' satisfaction and loyalty. Maximum likelihood estimation was employed to estimate the model. The final model fit the data well. More specifically, $\chi^{2}$ value is 108.335 with 92 degrees of freedom, $\mathrm{p}=.119$; GFI= 0.95; $\mathrm{AGFI}=0.92 ; \mathrm{NFI}=0.96 ; \mathrm{RFI}=0.93 ; \mathrm{IFI}=0.96 ; \mathrm{TLI}=0.96 ; \mathrm{CFI}=0.97$ and RMSEA $=0.036$. As well, the ratio of the two models is $108.335 / 92=$ 1.18 , hence, the model is stable and converges properly. Figure 2 depicts graphically the results of the final SEM for the passengers' satisfaction and loyalty. The large circle is latent variable, the rectangles are measured variables, and the single arrows denote regression paths (i.e. bold arrows denote significant paths and doted arrows denote non-significant paths). 


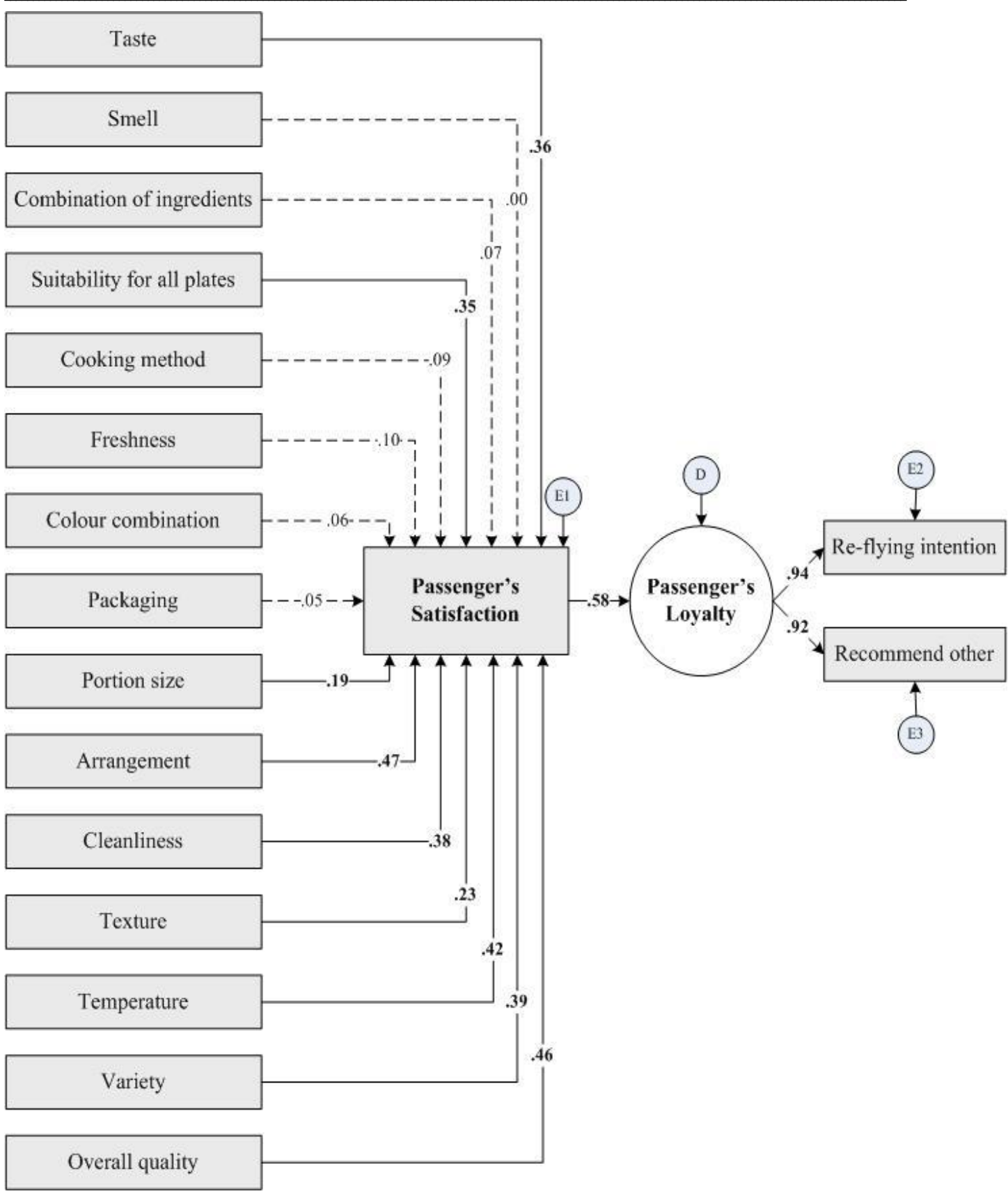

Figure 2: Final structure equation model and standardized estimates for passenger's satisfaction and loyalty

The unstandardized parameter estimates (i.e. factor loadings) of the structural model presented in Table 5 show that passenger's loyalty (i.e. re-flying intention, and recommending others) was predicted by passenger's satisfaction (factor loading $=0.56, \mathrm{p}<0.001$ ). In addition, passenger's satisfaction was predicted by the taste of the meal (factor loading $=0.35, \mathrm{p}<$ 
0.001 ), palatability (factor loading $=0.32, \mathrm{p}<0.001$ ), portion size (factor loading $=0.19, \mathrm{p}<0.001$ ), arrangement (factor loading $=0.47, \mathrm{p}<0.001$ ), cleanliness (factor loading $=0.37, \mathrm{p}<0.001$ ), texture (factor loading $=0.22$, $\mathrm{p}<0.001$ ), temperature (factor loading $=0.42, \mathrm{p}<0.001$ ), variety (factor loading $=0.39, \mathrm{p}<0.001$ ), and overall quality (factor loading $=0.46, \mathrm{p}<$ $0.001)$.

Table 5: The parameter estimates of the structural model

\begin{tabular}{|c|c|c|c|c|c|}
\hline Hypotheses & Path & $\begin{array}{c}\text { Factor } \\
\text { loadings }\end{array}$ & t-value & $\begin{array}{c}\text { Path } \\
\text { coefficients }\end{array}$ & Results \\
\hline H1 & $\mathrm{PS} \rightarrow \mathrm{PL}$ & 0.56 & 7.57 & 0.58 & Supported \\
\hline $\mathrm{H} 2$ & $\mathrm{TA} \rightarrow \mathrm{PS}$ & 0.35 & 3.94 & 0.36 & Supported \\
\hline $\mathrm{H} 3$ & $\mathrm{SM} \rightarrow \mathrm{PS}$ & 0.01 & 0.18 & 0.00 & Not supported \\
\hline $\mathrm{H} 4$ & $\mathrm{IN} \rightarrow \mathrm{PS}$ & 0.07 & 1.39 & 0.07 & Not supported \\
\hline H5 & $\mathrm{PL} \rightarrow \mathrm{PS}$ & 0.32 & 3.64 & 0.35 & Supported \\
\hline H6 & $\mathrm{ME} \rightarrow \mathrm{PS}$ & 0.08 & 1.67 & 0.09 & Not supported \\
\hline $\mathrm{H7}$ & $\mathrm{FR} \rightarrow \mathrm{PS}$ & 0.09 & 1.70 & 0.10 & Not supported \\
\hline H8 & $\mathrm{CO} \rightarrow \mathrm{PS}$ & 0.07 & 0.78 & 0.06 & Not supported \\
\hline H9 & $\mathrm{PA} \rightarrow \mathrm{PS}$ & 0.06 & 0.71 & 0.05 & Not supported \\
\hline $\mathrm{H} 10$ & $\mathrm{PO} \rightarrow \mathrm{PS}$ & 0.19 & 3.29 & 0.19 & Supported \\
\hline H11 & $\mathrm{AR} \rightarrow \mathrm{PS}$ & 0.47 & 8.91 & 0.47 & Supported \\
\hline $\mathrm{H} 12$ & $\mathrm{CL} \rightarrow \mathrm{PS}$ & 0.37 & 7.90 & 0.38 & Supported \\
\hline $\mathrm{H} 13$ & $\mathrm{TX} \rightarrow \mathrm{PS}$ & 0.22 & 3.59 & 0.23 & Supported \\
\hline $\mathrm{H} 14$ & $\mathrm{TE} \rightarrow \mathrm{PS}$ & 0.42 & 8.20 & 0.42 & Supported \\
\hline $\mathrm{H} 15$ & $\mathrm{VA} \rightarrow \mathrm{PS}$ & 0.39 & 7.96 & 0.39 & Supported \\
\hline H16 & $\mathrm{QU} \rightarrow \mathrm{PS}$ & 0.46 & 8.90 & 0.46 & Supported \\
\hline
\end{tabular}

\section{DISCUSSION AND IMPLICATIONS}

The current study explored the influence of on-board food attributes on passengers' satisfaction and their intention to re-use the same airline company. Firstly, passengers were compared on their scores by gender, age, airline company, frequency of travel, travelling class, and purpose of travel. The findings revealed that female passengers had higher scores than male passengers on the variety, and the overall quality of the meal served. Furthermore, older passengers had higher scores than younger passengers on almost all food attributes. Hence, airline companies should meet the expectations of younger and male passengers. The results also showed significant differences among airline companies regards taste, portion size, texture, and variety of meal. Specifically, the passengers of Emirates Air were highly satisfied with the taste of the meal, while the passengers of Egypt Air were highly satisfied with the variety of the meal offered. The passengers who were regularly travelling using the same airline companies were more satisfied with on-board meals. Therefore, airline passengers should meet the expectations of new customers. Finally, vacation passengers had the highest 
scores on portion size and variety of the meal, while business passengers had the highest scores on suitability of the meal for all plates.

Secondly, sixteen hypotheses were developed and tested. From which, ten hypotheses were supported. More specifically, this study showed that passengers' satisfaction with on-board meals had significant effect on their loyalty (i.e. re-flying intention and recommending others). This finding just supports prior research (e.g., O'Hara and Strugnell, 1997; Heide et al., 1999; Suzuki, 2004; Park et al., 2005). Therefore, airline companies should work very hard to meet passengers' expectations concerning on-board meals.

Additionally, in this study, some food attributes were significantly associated with higher passengers' satisfaction. More specifically, on-board meal taste, suitability for all plates, portion size, arrangement, cleanliness, texture, temperature, variety, and overall quality had significant impacts on passengers' satisfaction. These findings are in agreement to what extent with previously-published results (i.e. Khatib 1998; Mohd Zahari et al., 2011) which showed that quality of meals, quantity of meals, and menu selection had significant impact on the level of passengers' satisfaction. It is therefore viable to increase passengers' satisfaction by managing those factors proactively. For example, airline companies should give clear considerations to the variety of meals, portion size, and tray presentation, especially in economy class. Further, airlines should offer special meals to meet dietary or religious needs' of passengers.

Conclusively, this study is an attempt to assist passengers' requirements regarding on-board meals. By using these results, airline companies can place themselves in the front lines especially in this competitive, fast growing industry. In fact, knowing passengers' expectations would help in the overall improvement in airline companies' services and help in keeping customers and gain new ones. Therefore, it is important to the airline companies to innovate appealing and appropriate meals beside other service parts.

\section{LIMITAIONS AND SUGGESTIONS FOR FUTURE RESEARCH}

There are some limitations in this study. First, the sample of the study is limited to nine airline companies, so the results cannot be generalized. As such, the model needs to be tested in other airlines to broaden the generalizability of the model. Second, one of the methodological limitations in this study was the use of self-report questionnaires. In future studies, using qualitative methods, including interviews or focus groups, should provide broader understanding of the factors influencing passengers' satisfaction and loyalty. Despite these limitations, this study has useful implications for both scholars and airline managers. 


\section{REFERENCES}

Abdel-Atti, A. (2003). Evaluating the Quality of Food Service Offered in Railways. Master Thesis, Helwan University, Egypt, p. 116.

Anderson, E. W., \& Sullivan, M. W. (1993). The Antecedents and Consequences of Customer Satisfaction for Firms. Marketing Science, 12 (Spring), pp. 125-143.

Arbuckle, J. (2011). IMB SPSS AMOS 20 User's Guide. Mount Pleasant, SC: AMOS Development Corporation.

Bennet, M. B., \& Wood, R. C. (2002). Some Current Issues in Airline Catering. Journal of Tourism Management, 5 (4), pp. 295-299.

Bolton, R. N., \& Drew, J. H. (1991). A Multistage Model of Customers' Assessments of Service Quality and Value. Journal of Consumers Research, 17, pp. 375-384.

Bryman, A., \& Bell, E. (2007). Business Research Methods (Second edition). Oxford, Oxford University Press.

Chang, Y-H., \& Yeh, C-H. (2002). A Survey Analysis of Service Quality for Domestic Airlines. European Journal of Operational Research, 193, pp. 166177.

Chen, F-Y., \& Chang, Y-H. (2005). Examining Airline Service Quality from a Process Perspective. Journal of Air Transport Management, 11, pp. 79-87.

Cronin, J. J., Prady, M. K., \& Hult, T. M. (2000). Assessing the Effects of Quality, Value, Customer Satisfaction on Consumer Behavioural Intentions in Service Environment. Journal of Retailing, 76 (2), pp.193-216.

Dana, L. P. (1999). Korean Airlines: British Food Journal, 101 (5), pp. 113116.

Dolnicar, S., Grabler, K ., Grun, B., \& Kulnig, A. (2011). Key Drivers of Airline Loyalty. Tourism Management, 32 (5), pp.1020-1026.

Elaine, M. J. (2000). Consumer Attitude towards Branded Quick-service Foods on Domestic Coach Class In-flight Menu. PhD. Thesis, Oklahoma State University.

Eliot, K. M., \& Roach, D. W. (1993). Service Quality in the Airline Industry: Are Carriers Getting an Unbiased Evaluation from Consumers? Journal of Professional Services Marketing, 9 (2), pp. 40-53.

Eric, T., \& Laws, Y. (2005). Managing Passenger Satisfaction: Some Quality Issues in Airline Meal Service. Journal of Quality Assurance in Hospitality and Tourism, 6 (1/2), pp. 89-113.

Franklin, F. G. (1999). History of In-flight Catering: It All Began in 1903 with Orville Wright. Journal of Airline and Food Travel Service, 16 (2), pp. 21-29. Gourdin, K. M., \& Kloppenborg, T. J. (1991). Identifying Service Gaps in Commercial Air Travel: The First Step towards Quality Improvement. Transportation Journal, 1 (31-Fall 1991): pp. 22-30. 
Gursoy, D., Chen, M-H., \& Kim, H. J. (2005). The US Airlines Relative Positioning Based on Attributes of Service Quality. Tourism Management, 26, pp. 57-67.

Hair, J., Black, W., Babin, B., \& Anderson, R. (2010). Multivariate Data Analysis (Seventh edition). Upper Saddle River, NJ, USA: Prentice-Hall, Inc. Hatakka, M. (2000). Hygienic Quality of Foods Served on Aircraft. M.Sc. Thesis, The Faculty of Veterinary Medicine, University of Helsinki. pp. 7-24. Hayama, M. (2002). Investigation of the Job Roles and Competencies of Airline Catering Chefs in the USA and Japan. PhD. Thesis, University of Surrey.

Heide, M., Kjell, G., \& Marit, G. E. (1999). Industry Specific Measurement of Consumer Satisfaction: Experiences from the Business Travelling Industry. Journal of Hospitality Management, 18 (2), pp. 201-213.

Johnston, R., \& Lyth, D. (1991). Implementing the Integration of Customer Expectations and Operational Capacity. In S. W. Brown, E. Gummesson, B. Edwardsson, \& B. Gustavsson (Eds.), Service Quality: Multidisciplinary and Multinational Perspectives (pp. 45-68). Stephen Walter Brown, Lexington Books..

Jones, P. (1995). Developing New Products and Services In-flight Catering. International Journal of Contemporary Hospitality Management, 7 (2), pp. 2428.

Jones, P. (2004). Flight Catering. Oxford, Butterworth Heinemann.

Jones, P. (2007). Flight Catering. Available at: http://www.epubs.surrey.ac.uk/2200 /2/E66589A3.pdf [Accessed on: 20 March 2014].

Khatib, F. (1998). An Investigation of Airline Service Quality, Passenger Satisfaction and Loyalty: The Case of Royal Jordanian Airline. PhD. Thesis, Sheffield University, UK.

King, T. (2001). In-flight Catering. Journal of Tourism and Hospitality Research, 3 (2), pp. 181-184.

Kirk, D. (1995). Flight Production Operations. Available at: http://www.ifca.net.com [Accessed on: 20 May 2013].

Liou J. J., \& Tzeng, G-H. (2007). A Non-additive Model for Evaluating Airline Service Quality. Journal of Air Transport, 13, pp. 131-138.

Makens, J. C., \& Marquardt, R. A. (1977). Consumer Perceptions Regarding First Class and Coach Airline Seating. Journal of Travel Research, 16 (1), pp.15-25.

McCool, A. C. (1995). Progressive Catering: A Comprehensive Treatment of Food, Cookery, Drink, Catering Services and Management. London, The Caxton Publishing Company Limited, pp. 54-82. 
Mohd Zahari, M. S., Salleh, N. K., Kamaruddin, M. S., \& Kutut, M. Z. (2011). In-flight Meals, Passengers' Level of Satisfaction and Re-flying Intention. World Academy of Science, Engineering and Technology, 6, pp. 20-32.

Nomani, A. (1999). Carry-on Food Really Taking off as Airlines Cut Back. The Arizona Republic, 12, pp. 5-12.

O'Hara, L., \& Strugnell, C. (1997). Development in In-flight Catering. Journal of Nutrition and Food Science, 3 (20), pp. 105-106.

Ostrowski, P. L., O'Brien, T. V., \& Gordon, G. L. (1993). Service Quality and Customer Loyalty in the Commercial Airline Industry. Journal of Travel Research, XXXII (2), pp. 16-24.

Park, J. W., Robertson, R., \& Wu, C. L. (2005). Investigating the Effect of Airline Service Quality on Airline Passengers' Future Behavioural Intentions. Journal of Tourism Studies, 16 (1), pp. 67-87.

Rust, R. T., \& Oliver, R. C. (1994). Service Quality: Insights and Managerial Implications from the Frontier. In: R.T. Rust, \& R. C. Oliver (Eds.), Service Quality: New Directions in Theory and Practice (pp. 1-20). London, Sage Publication.

Selin, S., Howard, D., Udd, E., \& Cable, T. (1988). An Analysis of Consumer Loyalty to Municipal Recreation Programs. Leisure Sciences, 10, pp. 210-223.

Solomon, M. R. (2002). Consumer Behaviour: International Edition (fifth edition). New Jersey, Prentice Hall.

Suzuki, Y. (2004). The Impact of Airline Service Failures on Travellers' Carrier Choice: A Case Study of Central Iowa. Transportation Journal, 3 (20), pp. 26-36.

Tabachnick, B., \& Fidell, L. (2007). Using Multivariate Statistics (Fifth edition). Boston, Pearson Education, Inc.

Taylor, S. A., \& Baker, T. L. (1994). An Assessment of the Relationship Between Service Quality and Customer Satisfaction in the Formation of Consumers' Purchase Intentions. Journal of Retailing, 70 (2), pp. 163-178.

Thorpe, V. (1998). In-flight Meals Was a Dog's Dinner. London Newspaper, 3, p. 5 .

Tiernan, S., Rhoades, D. L., \& Waguespack, B. (2008). Airline Service Quality: Exploratory analysis of Consumer Perceptions and Operational Performance in the USA and EU. Managing Service Quality, 18 (3), pp. 212224.

Tu, A. (1997). Catering to Passengers. On-board Services, 29 (9), p. 14.

Williams, K. (1995). Better Eat Before you Fly. Capital Times, 4, p. 9.

Wright, C. (2001). Table in the Sky: Recipe from the British Airways and the Great Chefs. London, Allen and Co. 